\title{
Mobile Hybrid Application Sebagai Solusi Dalam Pelaporan Bencana Menggunakan Framework Cordova
}

\author{
Ari Muzakir ${ }^{\left.1^{*}\right)}$ Eksen Hidiansah ${ }^{2)}$ \\ ${ }^{1,2}$ Program Studi Teknik Informatika, Fakultas Komputer, Universitas Bina Darma, Palembang ${ }^{1,2}$ \\ Jln. A. Yani No.03 Plaju, Kota Palembang, 30264, Indonesia \\ Email: ${ }^{1}$ arimuzakir@.binadarma.ac.id, ${ }^{2}$ hidiansyah@gmail.com
}

Received: 29 Maret 2018; Revised:11 Mei 2018; Accepted: 14 Mei 2018

Copyright $@ 2018$ Politeknik Harapan Bersama Tegal. All rights reserved

\begin{abstract}
Mobile devices are now almost used by all walks of life. Various platforms available on smartphones like Android, iOS, Windows Mobile provide great opportunities and become a challenge for app developers. The problem is that app developers need to be able to match the needs of the available platform. The solution to this problem is the mobile hybrid application technology, which enables application developers to bridge every different smartphone platform using the cordova framework. The cordova framework allows application developers to build mobile applications using HTML5, CSS, and javascript (JS). In this research more focused on testing the technology of mobile hybrid application to build mobile application of disaster reporting at Regional Disaster Management Agency (BPBD) South Sumatera. Test results in the form of android and windows phone applications through several tests, among others, ease in the process of building applications, publishing, and configuration. It is expected that this hybrid mobile application software can help disaster management agencies in southern Sumatra region in disaster preparedness in the community.
\end{abstract}

Abstrak - Perangkat mobile saat hampir digunakan oleh seluruh lapisan masyarakat. Berbagai platform yang tersedia pada smartphone seperti Android, iOS, Windows Mobile memberikan peluang yang besar serta menjadi tantangan bagi pengembang aplikasi. Masalahnya adalah bahwa pengembang aplikasi harus mampu menyesuaikan kebutuhan dari platform yang tersedia. Solusi dari masalah tersebut adalah teknologi mobile hybrid application, dimana teknologi ini memungkinkan pengembang aplikasi dalam menjembatani setiap platform smartphone yang berbeda-beda menggunakan framework cordova. Framework cordova memungkinkan pengembang aplikasi membangun mobile application dengan menggunakan HTML5, CSS, dan javascript (JS). Dalam penelitian ini lebih fokus pada ujicoba teknologi mobile hybrid application untuk membangun aplikasi mobile pelaporan bencana pada Badan penanggulangan bencana Daerah (BPBD) Sumatera Selatan. Hasil ujicoba berupa aplikasi android dan windows phone melalui beberapa pengujian antara lain kemudahan dalam proses build aplikasi, publishing, dan konfigurasi. Diharapkan dengan perangkat lunak aplikasi mobile hybrid ini dapat membantu lembaga penanggulangan bencana di wilayah Sumatera bagian selatan dalam kesiapan menghadapi bencana yang terjadi di masyarakat.

Kata Kunci - Framework Cordova, Cross-platform, Mobile hybrid Application, HTML5, hybrid programming.

*) Corresponding author: Ari Muzakir

Email: arimuzakir@binadarma.ac.id

\section{PENDAHULUAN}

Dengan semakin meningkatnya beberapa kejadian bencana alam di wilayah Sumatera Selatan, hal ini tentunya menjadi evaluasi yang penting bagi Badan Penanggulangan Bencana (BPBD). Hal ini dilihat dari frekuensi bencana yang terjadi pada tahun 2016 sebanyak 195 bencana alam, dimana hal ini meningkat 49 kali dibanding tahun 2015 lalu sebanyak 146 bencana. Bencana yang terjadi seperti kebakaran lahan, banjir, angin puting beliung, dan longsor yang terjadi di 17 kabupaten kota di Sumatera Selatan. Dengan meningkatnya tuntutan untuk optimalisasi penanganan bencana tersebut, maka perlu difikirkan solusi yang tepat agar informasi yang diterima efektif dan cepat tanggap. Teknologi mobile smartphone menjadi alternatif dari sekian banyak solusi yang ada untuk proses pelaporan yang mudah dan cepat [1][2]. Proses pelaporan yang saat ini biasa dilakukan oleh masyarakat adalah dengan menggunakan fitur telepon dan short message service (SMS). Tidak adanya media penghubung antara badan penanggulangan bencana daerah sumatera selatan dengan masyarakat menyebabkan masyarakat mengalami kesulitan dalam penyampaian informasi bencana yang terjadi saat itu. Untuk mempermudah masyarakat untuk menyampaikan informasi bencana yang terjadi maka dibutuhkan suatu sistem yang bisa melibatkan masyarakat dalam kesiapsiagaan dalam menghadapi bencana. Saat ini hampir seluruh lapisan masyarakat telah memiliki smartphone dengan berbagai platform. Berbagai platform smartphone menjadi kendala baru dalam proses pengembangan aplikasi.

Secara umum, ujicoba mobile hybrid application dalam penelitian ini dilakukan pada sistem pelaporan bencana yang ada di Sumatera Selatan dengan output capaian berupa aplikasi yang berjalan di platform android dan windows mobile. Struktur pemrograman yang digunakan menggunakan HTML5, CSS, dan Javascript sebagai komponen aplikasi client (frontend user) [3]. Sedangkan untuk backend menggunakan pemrograman PHP dengan database MySQL. Tool yang digunakan dalam penyelesaian aplikasi ini memanfaatkan integrated development environment (IDE) secara online dari Monaca yang merupakan suatu tools dan services untuk membangun suatu sistem mobile hybrid application dengan menggunakan HTML5 dan Phonegap. IDE Monaca sangat memungkinkan dalam membangun aplikasi lintas platform seperti Android, iOS, Windows Phone 
dan lain sebagainya karena dibagun diatas aplikasi open source Cordova [4][5]. Kerangka (framework) untuk pengembangan aplikasi hybrid dipisahkan menjadi dua jenis, mereka yang bertanggung jawab untuk antarmuka (UI - user interface), dan yang bertanggung jawab untuk mengemas aplikasi menjadi platform yang berbeda dan memungkinkan untuk mengakses fitur telepon [6].

Terlepas dari platform, aplikasi mobile hybrid dapat berjalan pada komponen browser (dukungan cross-platform) yang dimiliki oleh smartphone [3]. Dengan kata lain, aplikasi mobile hybrid dapat berjalan pada beberapa platform seperti Android, iOS, Windows Phone, dan platform lain yang mendukung HTML5 browser karena berjalan pada komponen WebView yang dimiliki oleh platform tersebut.

\section{PENELITIAN YANG TERKAIT}

Pada penelitian sebelumnya yang dilakukan oleh Ari Muzakir pada tahun 2017 dengan judul Prototyping aplikasi e-health sebagai bagian pengenalan obat-obatan dengan teknologi cross-platform [7]. Hasil dari penelitian ini yaitu membantu masyarakat untuk mempelajari mengenai obatobatan dengan bantuan aplikasi yang dibangun dengan teknologi cross-platform pada perangkat Android.

Penelitian yang dilakukan oleh Suardika tahun 2015 dengan judul rancang bangun sistem informasi E-Research STIKOM Bali Multi Platform Smartphone berbasis Phonegap, hasil akhir menunjukkan bahwa Eresearch STIKOM Bali dapat diimplementasikan kedalam aplikasi mobile pada beberapa platform smartphone dengan menggunakan satu source code dengan aplikasi PhoneGap [8].

Selanjutnya pada penelitian yang berkaitan dengan aplikasi mobile ini dilakukan oleh Ari Muzakir pada tahun 2016 dengan judul Framework Phonegap Sebagai Teknologi Cross-platform Mobile Development: Studi Kasus Kamus Tumbuhan [9]. Penelitian tersebut telah di publikasikan pada konferensi nasional teknologi informasi dan aplikasinya (KNTIA). Hasil penelitian ini adalah melakukan ujicoba teknologi cross-platform dalam proses pengembangan aplikasi mobile lintas platform yaitu android, iOS, dan windows phone. Metode pengembangan sistem yang digunakan dalam penelitian tersebut adalah Mobile-D.

Sedangkan pada penelitian yang dilakukan adalah ujicoba implementasi mobile hybrid dengan teknologi cordova untuk membuat aplikasi pelaporan bencana yang ada di BNSP provinsi Sumatera Selatan.

\section{METODE PENELITIAN}

Mobile hybrid application dipilih dalam teknik pembuatan aplikasi cross platform karena sifatnya yang sekali coding maka dapat digunakan atau di install ke beberapa platform yang berbeda [10]. Adapun sifat dari mobile hybrid ini dapat dilihat pada Gbr.1.

Metode penelitian yang digunakan adalah metode deskriptif kualitatif yang disesuaikan dengan metode pengembangan perangkat lunak. Dalam aplikasinya, proses analitik dilakukan dengan mengamati objek-objek pengguna yang terkait dengan alur pelaporan bencana alam. Model yang digunakan dalam pengembangan aplikasi ini menggunakan prototype. Tahapan-tahapan yang ada dalam model prototype ini yaitu communication, quick plan, modeling quick design, construction of prototype, deployment delivery \& feedback [11].

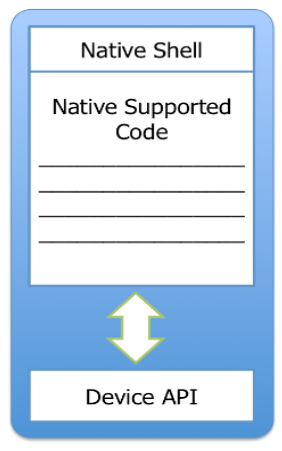

Native Apps

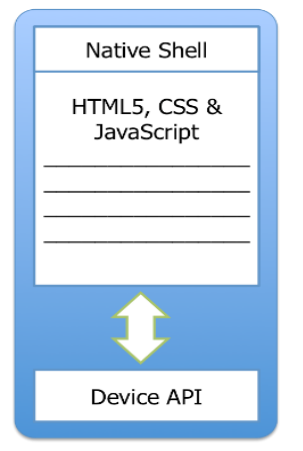

Hybrid Apps

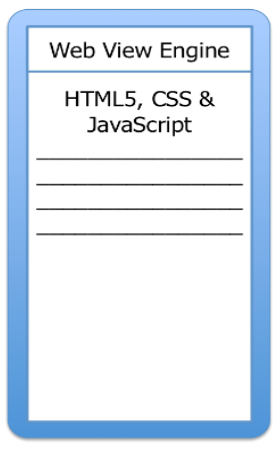

Web Apps
Gbr. 1 Alur proses pengaksesan dalam aplikasi [10]

\section{A. Analisis Sistem}

Menurut tahap awal dalam model prototype, ada kegiatan mendengarkan klien dan pengumpulan data awal, analisis kebutuhan pengguna yaitu menentukan data-data yang dibutuhkan dalam pembuatan aplikasi pelaporan bencana alam yang ada di Sumatera Selatan. Komunikasi (komunikasi) dibuat di beberapa pihak yang berkepentingan, seperti aktor yang akan menggunakan dalam sistem. Kata aktor adalah administrator dan klien yang akan menggunakan sistem.

Analisis ini digunakan untuk mendefinisikan dan menggambarkan kebutuhan sistem secara detail dan mencakup ruang lingkup sistem itu sendiri. Hasil analisis ini berupa desain sistem yang akan menjadi acuan dalam pengembangan sistem untuk tahap selanjutnya. Analisis persyaratan sistem menentukan bagaimana pengguna, data, proses dan teknologi informasi dapat saling terhubung. Dengan analisis persyaratan sistem, diharapkan bahwa hal itu akan dijelaskan secara rinci dalam komponen sistem dengan tujuan mengidentifikasi, mengevaluasi masalah dan kebutuhan sesuai yang diharapkan.

Adapun untuk membangun antarmuka pada aplikasi ini menggunakan antarmuka Onsen UI. Onsen Framework UI sendiri terdiri dari HTML5, CSS, dan Javascript (AngularJs) yang biasa digunakan dalam membangun sistem berbasis web [12][13].

Dalam implementasi di masa depan, pengguna akan dapat mengakses melalui aplikasi yang diinstal di smartphone untuk kebutuhan pelaporan bencana alam. Seluruh proses dalam aplikasi ini akan selalu terhubung menggunakan internet untuk dapat menggunakannya. Dalam kasus permintaan dan tanggapan, data akan melibatkan modul antarmuka pemrograman aplikasi (API), dalam modul API mencakup fungsi permintaan basis data. Selain itu ada juga dasbor untuk masuk sebagai administrator untuk memperbarui semua konten aplikasi pelaporan bencana tersebut. Berikut gambaran mengenai alur aplikasi yang diterapkan pada Gbr 2 . 


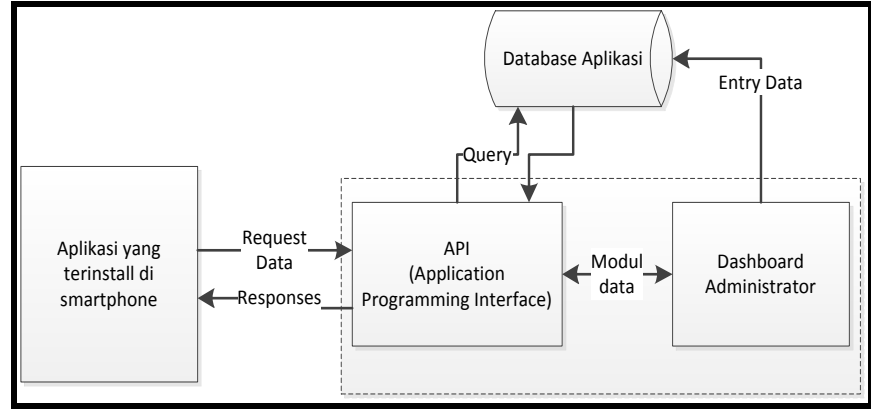

Gbr.2 Arsitektur alur aplikasi yang akan dibangun

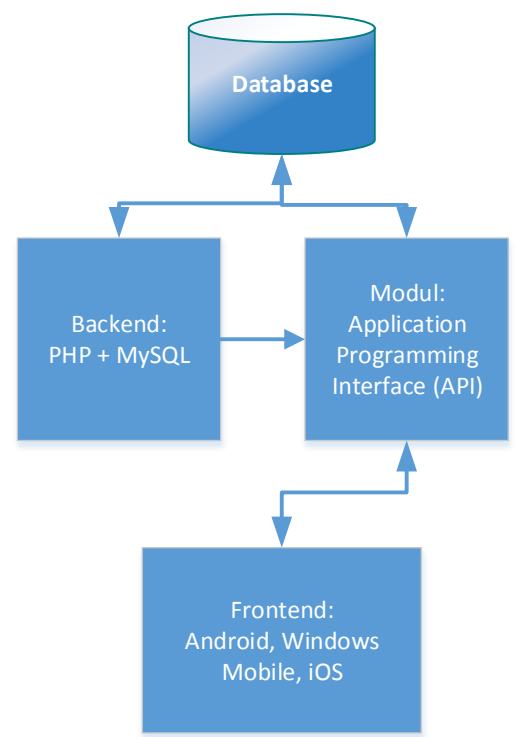

Gbr. 3 Alur proses pengaksesan dalam aplikasi

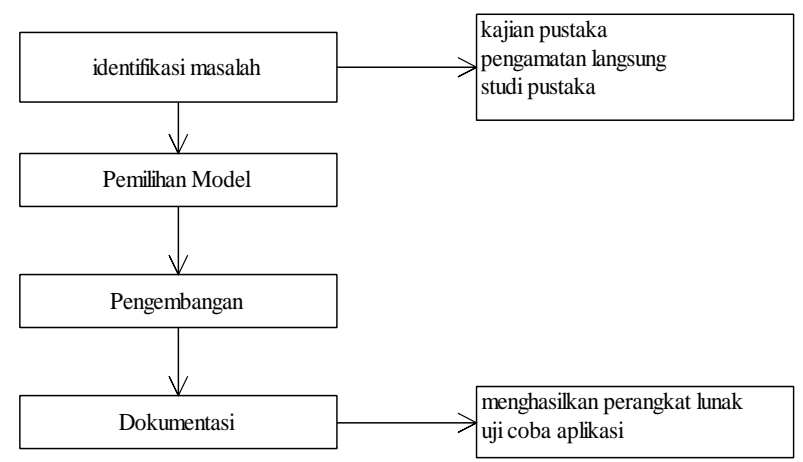

Gbr. 4 Alur kerangka pemikiran

Adapun spesifikaksi kebutuhan sistem dalam membangun aplikasi pengukuran waktu kerja ini adalah:

- Sistem operasi : Microsoft Windows atau Linux

- Editorial : Sublime, Notepad ++ (untuk editor script)

- Bahasa Scripting : HTML5, PHP, Javascript, CSS

- Aplikasi Toolkit : Microsoft visio, star UML

- Web server : Xampp (paket MySQL dan Apache)

Selain itu, untuk menentukan persyaratan fungsional yang terkait dengan fungsionalitas dan kemampuan sistem, pengguna nantinya akan mengakses melalui aplikasi yang diinstal pada smartphone. Seluruh proses dalam aplikasi ini akan selalu terhubung melalui jaringan internet untuk menggunakannya. Dalam kasus permintaan dan tanggapan, data akan melibatkan antarmuka pemrograman aplikasi (API), yang dalam modul API tersebut memiliki fungsi kueri untuk database, pada Gbr.3. Saat ini, aliran sistem yang berjalan proses pelaporan setiap terjadi bencana alam adalah dengan menggunakan telpon atau datang langsung ke BNPB di wilayah tersebut. Untuk itu, maka dibuatlah alur atau kerangka pemikiran dalam proses pembuatan aplikasi pelaporan bencana tersebut seperti pada Gbr.4.

Dari kerangka pemikiran tersebut bahwa yang dilakukan pertama kali adalah melakukan identifikasi masalah yang muncul dalam hal pelaporan bencana. Identifikasi tersebut juga melibatkan kajian pustaka terkait dengan topik antara lain observasi, wawancara, dan studi pustaka. Selanjutnya adalah pemilihan model yang tepat dalam pelaksanaan penyelesaian permasalahan tersebut, sehingga model tersebut tepat dalam proses implementasi ke pengembangan.

\section{B. Perancangan Sistem}

Desain adalah tahap berikutnya dari prototipe, pada tahap ini proses desain mengubah kualitas menjadi representasi perangkat lunak yang dapat diprediksi sebelum dimulainya pembuatan kode.

\section{1) Usecase Diagram}

Desain dibangun dengan bahasa pemodelan bahasa pemodelan terpadu menggunakan usecase. Pada penelitian ini melibatkan 3 pengguna yang akan menggunakan sistem, yaitu pelapor, petugas kantor, dan petugas lapangan. Adapun user system modelling dibawah ini akan dimulai dengan aktor petugas login untuk masuk ke sistem, mengelola data pelapor, mengelola data laporan bencana, mengelola data petugas dan logout untuk keluar dari sistem. Selanjutnya aktor pelapor melakukan pendaftaran untuk mendapatkan username dan password agar bisa masuk ke aplikasi. Kemudian dilanjutkan dengan pelapor bisa melaporkan bencana dan membaca informasi mengenai bencana dan logout untuk keluar dari sistem. Lebih lengkapnya dapat dilihat seperti pada Gbr 5.

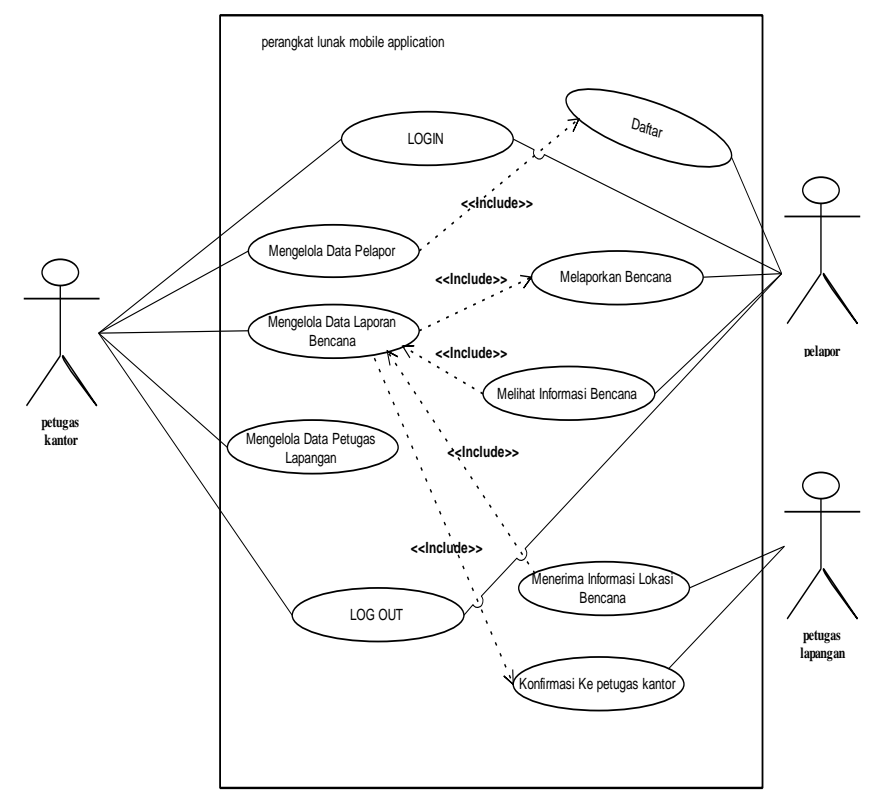

Gbr. 5 User system modelling 
Adapun peran dari aktor tersebut adalah:

- Pelapor: melakukan pendaftaran ke system untuk dapat melaporkan bencana yang terjadi, melihat informasi bencana yang sedang berlangsung.

- Petugas kantor: bertindak melakukan pengolahan data pelapor, mengelola data petugas lapangan, dan mengelola data laporan bencana yang dilaporkan oleh pelapor.

- Petugas lapangan: akan menerima informasi lokasi bencana yang dilaporkan oleh pelapor dan mengkonfirmasi dari petugas kantor.

\section{2) Activity Diagram}

Activity diagram menggambarkan berbagai aktivitas pengguna mengalir di dalam sistem. Pada penelitian ini ada 2 activity yang buat sebagai gambaran aktivitas pengguna yaitu activity pelapor dan activity petugas. Pada diagram aktivitas perangkat lunak mobile hybrid untuk pelapor dapat dilihat pada Gbr.6.

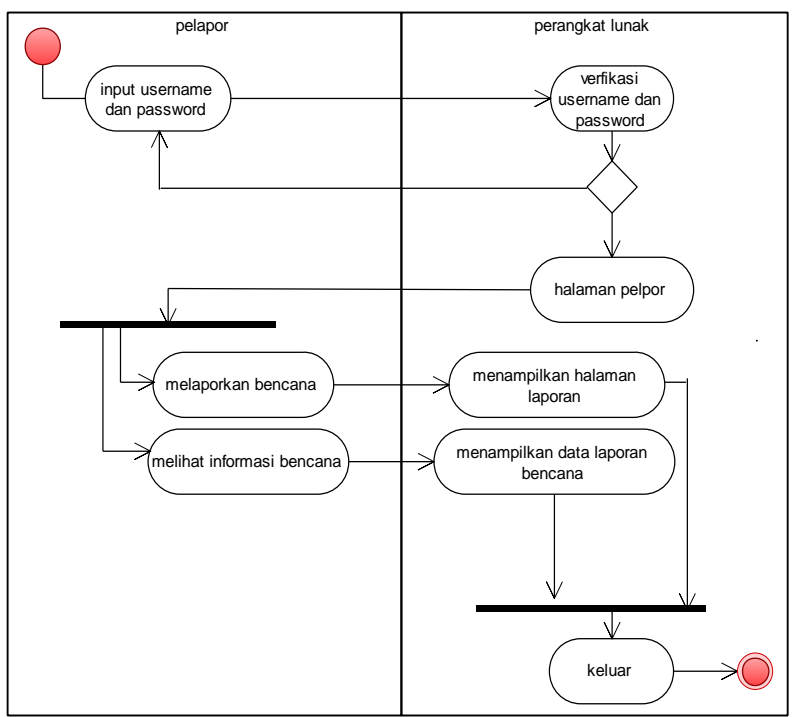

Gbr. 6 Activity diagram pelapor

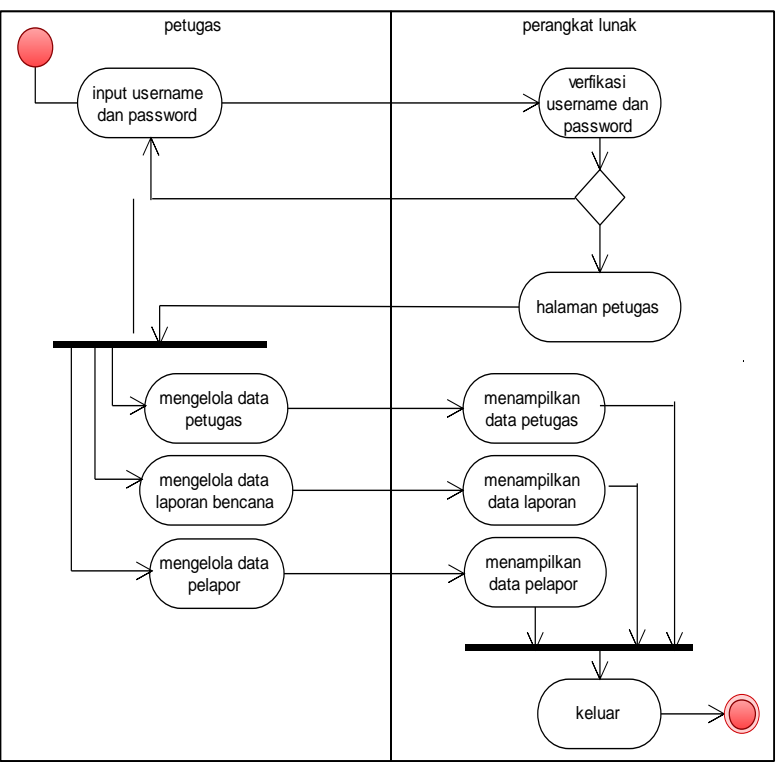

Gbr. 7 Activity diagram petugas
Kemudian untuk menanggapi laporan dari pelapor, maka dibuatlah activity diagram untuk petugas agar informasi laporan dapat didisposisi ke petugas lapangan. Berikut activity diagram petugas seperti pada Gbr.7.

\section{HASIL DAN PEMBAHASAN}

Setelah melalui analisis persyaratan sistem dan desain desain yang terkait dengan aplikasi yang dibuat dalam penelitian, hasil dari aplikasi sistem diperoleh. Hasil yang didapat ada 2 jenis sistem berbasis web dan sistem Android berbasis mobile. Hasil yang diperoleh dari penelitian di Badan Regional Penanggulangan Bencana Sumatera del Sur adalah perangkat lunak aplikasi mobile hybrid yang menggunakan teknologi cordova, studi kasus, badan penanggulangan bencana dari wilayah Sumatera Selatan. Hasil dari ujicoba dilakukan menggunakan IDE monaca yang dapat diakses secara online seperti pada Gbr. 8.

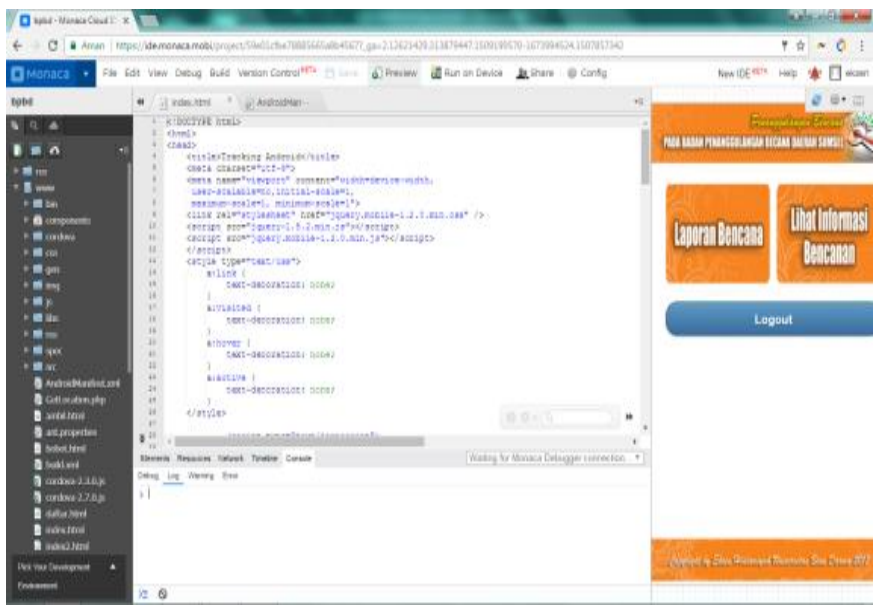

Gbr. 8 Aplikasi berbasis web untuk dashboard Administrator

TABEL I

PENGUJIAN BUILD APLIKASI

\begin{tabular}{|c|c|c|c|}
\hline \multirow{2}{*}{$\begin{array}{c}\text { Jenis } \\
\text { Pengujian }\end{array}$} & \multicolumn{2}{|c|}{ Jenis Smartphone } & \multirow[b]{2}{*}{ Keterangan Hasil } \\
\hline & Android & $\begin{array}{l}\text { Windows } \\
\text { Phone }\end{array}$ & \\
\hline Build aplikasi & berhasil & berhasil & $\begin{array}{l}\text { Android berhasil harus } \\
\text { menggunakan } \\
\text { keystrore yang valid - } \\
\text { windows phone } \\
\text { berjalan pada windows } \\
\text { phone } 8 \mathrm{x} \text {-ios } \\
\text { membutuhkan } \\
\text { sertifikat devolepmnt } \\
\text { key dari apple }\end{array}$ \\
\hline $\begin{array}{l}\text { Konfigurasi } \\
\text { App }\end{array}$ & mudah & mudah & $\begin{array}{l}\text { keystrore setting, build } \\
\text { seting }\end{array}$ \\
\hline $\begin{array}{l}\text { File Installer } \\
\text { for testing }\end{array}$ & file .apk & file .appx & $\begin{array}{l}\text { Untuk IOS langsung di } \\
\text { publish ke app store }\end{array}$ \\
\hline Publish & Playstore & $\begin{array}{l}\text { Microsoft } \\
\text { Store }\end{array}$ & \\
\hline
\end{tabular}

Perangkat lunak ini dikembangkan dengan metode mobile hybrid pengembangan perangkat lunak mobile multiplatform berarti bahwa perangkat lunak ini dapat digunakan oleh beberapa sistem operasi terkemuka, seperti Android, Windows Phone, iOS. Untuk aplikasi mobile dilakukan 
pengujian dari segi kemudahan build aplikasi seperti pada tabel I.

Untuk ujicoba pertama kali dilakukan pada menggunakan jaringan localhost untuk dapat memastikan bahwa fungsionalitas dari aplikasi telah berjalan sesuai yang diharapakan. Setelah aplikasi sesuai 90\% dari yang direncanakan, maka seluruh modul aplikasi dipindahkan ke hosting dan domain. Berikut dapat dilihat pada Gbr. 9 tampilan aplikasi berbasis web. Pada Gbr.9 terdapat beberapa fasilitas yang memungkinkan administrator untuk memasukkan data yang terkait dengan laporan data bencana. Selain informasi yang ditampilkan dalam aplikasi pengguna (aplikasi Android pada Gbr.10).
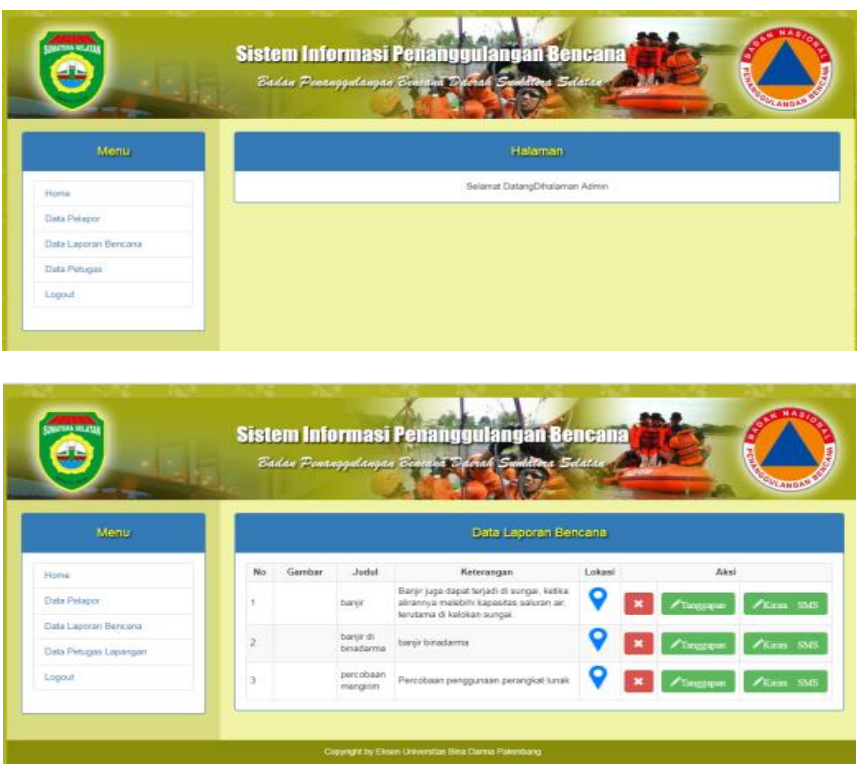

Gbr. 9 Aplikasi berbasis web untuk dashboard Administrator
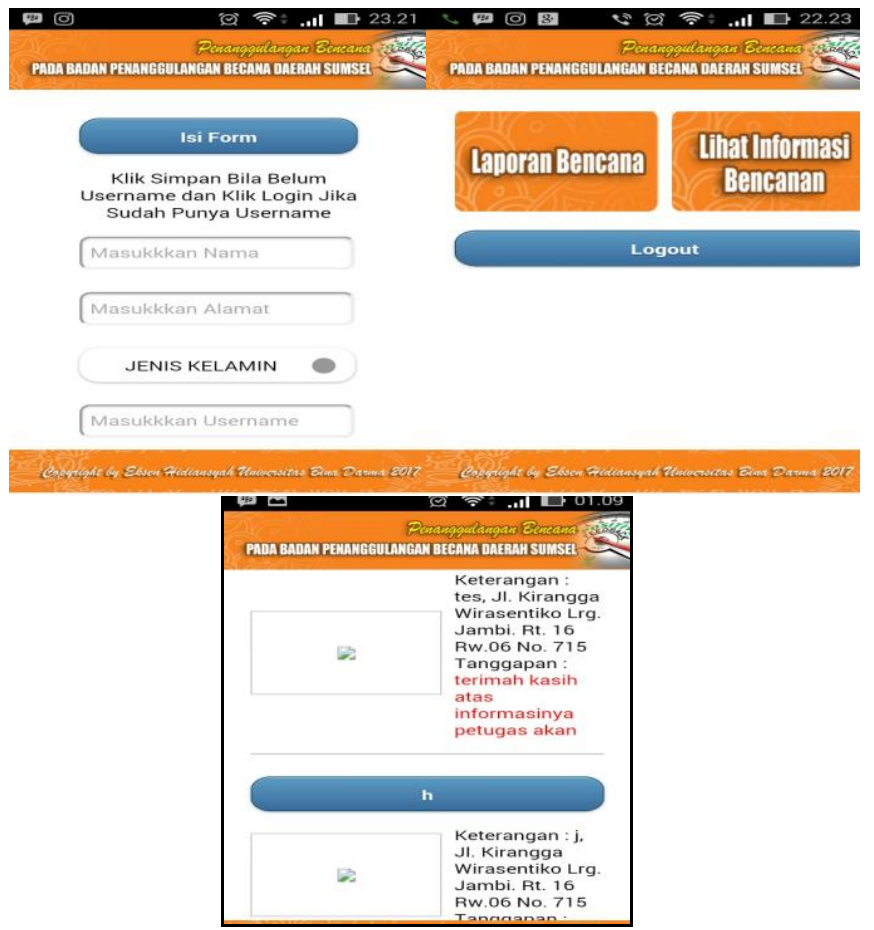

Gbr. 10b Aplikasi Android untuk pelapor
Pada halaman daftar laporan adalah halaman yang harus diselesaikan oleh pengguna perangkat lunak ponsel saat pertama kali menggunakan sistem, di halaman ini pengguna harus mengisi data, yaitu nama, alamat, jenis kelamin, nama pengguna dan kata sandi. Dengan melengkapi data dalam formulir ini, pengguna akan memperoleh nama pengguna dan kata sandi untuk entri biasa atau masuk ke perangkat lunak mobile. halaman yang digunakan oleh pelapor untuk melaporkan bencana pada halaman ini pelapor wajib mengisi judul, keterangan dan lokasi yang otomatis akan terisi sesuat lokasi perangkat. Setelah melakukan percobaan pada perangkat baik web dan mobile, maka tahapan selanjutnya adalah melakukan pengujian sederhana menggunakan metode blackbox. Metode ini akan mengukur kemampuan aplikasi berdasarkan fungsi masukan dan keluaran, siperlihatkan pada tabel II dan tabel III.

TABEL II

PENGUJian Fungsi APLIKASI AdMIN (WEB)

\begin{tabular}{|c|c|c|c|c|}
\hline \multirow{2}{*}{ Deskripsi } & \multirow{2}{*}{$\begin{array}{l}\text { Prosedur } \\
\text { pengujian }\end{array}$} & \multicolumn{2}{|c|}{ Interface } & \multirow[t]{2}{*}{ Kesimpulan } \\
\hline & & Petugas & Pelapor & \\
\hline $\begin{array}{l}\text { Pengujian } \\
\text { halaman } \\
\text { daftar }\end{array}$ & $\begin{array}{l}\text { Menginput } \\
\text { kan nama, } \\
\text { alamat, } \\
\text { jenis } \\
\text { kelamin, } \\
\text { username, } \\
\text { password }\end{array}$ & tidak & ya & $\begin{array}{l}\text { Sukses pelapor } \\
\text { berhasil melaukan } \\
\text { login }\end{array}$ \\
\hline $\begin{array}{l}\text { Pengujian } \\
\text { halaman } \\
\text { login }\end{array}$ & $\begin{array}{l}\text { Menginput } \\
\text { kan } \\
\text { username } \\
\text { dan } \\
\text { password }\end{array}$ & ya & ya & $\begin{array}{l}\text { Sukses petugas } \\
\text { dan pelapor } \\
\text { berhasil } \\
\text { melakukan login }\end{array}$ \\
\hline $\begin{array}{l}\text { Pengujian } \\
\text { menampilk } \\
\text { an data } \\
\text { laporan }\end{array}$ & $\begin{array}{l}\text { Memilih } \\
\text { menu data } \\
\text { laporan } \\
\text { bencana }\end{array}$ & ya & tidak & $\begin{array}{l}\text { Sukses data } \\
\text { laporan bencana } \\
\text { berhasil } \\
\text { ditampilkan }\end{array}$ \\
\hline $\begin{array}{l}\text { Pengujian } \\
\text { halaman } \\
\text { laporan } \\
\text { bencana }\end{array}$ & $\begin{array}{l}\text { Memilih } \\
\text { menu } \\
\text { laporan } \\
\text { bencana }\end{array}$ & tidak & ya & $\begin{array}{l}\text { Sukses halaman } \\
\text { berhasil mengirim } \\
\text { data laporan }\end{array}$ \\
\hline $\begin{array}{l}\text { Pengujian } \\
\text { halaman } \\
\text { lihat lokasi } \\
\text { bencana }\end{array}$ & $\begin{array}{l}\text { Memilih } \\
\text { menu } \\
\text { lokasi pada } \\
\text { laporan } \\
\text { bencana }\end{array}$ & ya & tidak & $\begin{array}{l}\text { Sukses lokasi } \\
\text { berhasil } \\
\text { ditampilkan di } \\
\text { map }\end{array}$ \\
\hline $\begin{array}{l}\text { Pengujian } \\
\text { halaman } \\
\text { tanggapan }\end{array}$ & $\begin{array}{l}\text { Memilih } \\
\text { menu } \\
\text { tanggapan } \\
\text { pada } \\
\text { halaman } \\
\text { laporan }\end{array}$ & ya & tidak & $\begin{array}{l}\text { Sukses laporan } \\
\text { berhasil } \\
\text { ditanggapi }\end{array}$ \\
\hline $\begin{array}{l}\text { Pengujian } \\
\text { llihat data } \\
\text { pelapor }\end{array}$ & $\begin{array}{l}\text { Memilih } \\
\text { menu data } \\
\text { pelapor }\end{array}$ & ya & tidak & $\begin{array}{l}\text { Sukses petugas } \\
\text { perangkat lunak } \\
\text { berhasil } \\
\text { menampikan data- } \\
\text { data pelapor }\end{array}$ \\
\hline $\begin{array}{l}\text { Pengujian } \\
\text { halaman } \\
\text { lihat } \\
\text { informasi } \\
\text { bencana }\end{array}$ & $\begin{array}{l}\text { Memilih } \\
\text { menu lihat } \\
\text { informasi } \\
\text { bencana }\end{array}$ & tidak & ya & $\begin{array}{l}\text { Sukses data } \\
\text { laporan bencana } \\
\text { berhasil } \\
\text { ditampilkan baik } \\
\text { itu informasi } \\
\text { bencana yang } \\
\text { sudah di tanggapi } \\
\text { maupun yang baru } \\
\text { dilaporkan. }\end{array}$ \\
\hline
\end{tabular}

Pada tabel II merupakan pengujian fungsional dari aplikasi berbasis web yang dipergunakan oleh administrator, 
sedangkan pada tabel III merupakan pengujian untuk aplikasi pengguna (aplikasi berbasis mobile android).

TABEL III

PENGUJiAn Fungsi APLIKASI USER (ANDROID)

\begin{tabular}{|l|l|l|l|c|}
\hline No & $\begin{array}{l}\text { Fungsi yang } \\
\text { di uji }\end{array}$ & Cara pengujian & $\begin{array}{c}\text { Halaman } \\
\text { yang } \\
\text { Diharapkan }\end{array}$ & $\begin{array}{c}\text { Hasil } \\
\text { pengujian }\end{array}$ \\
\hline 1 & Home user & $\begin{array}{l}\text { User membuka } \\
\text { plikasi pada } \\
\text { smartphone }\end{array}$ & $\begin{array}{l}\text { Halaman home } \\
\text { Atau utama }\end{array}$ & Berhasil \\
\hline 2 & $\begin{array}{l}\text { Halaman } \\
\text { Laporan } \\
\text { bencana }\end{array}$ & $\begin{array}{l}\text { user } \text { meng-klik } \\
\text { button laporan } \\
\text { bencana }\end{array}$ & $\begin{array}{l}\text { Halaman form } \\
\text { laporan } \\
\text { bencana } \\
\text { muncul }\end{array}$ & Berhasil \\
\hline 3 & $\begin{array}{l}\text { Halaman } \\
\text { Informasi } \\
\text { laporan } \\
\text { bencana }\end{array}$ & $\begin{array}{l}\text { User meng-klik } \\
\text { button lihat } \\
\text { informasi } \\
\text { laporan bencana }\end{array}$ & $\begin{array}{l}\text { Halaman } \\
\text { informasi } \\
\text { laporan muncul }\end{array}$ & Berhasil \\
\hline
\end{tabular}

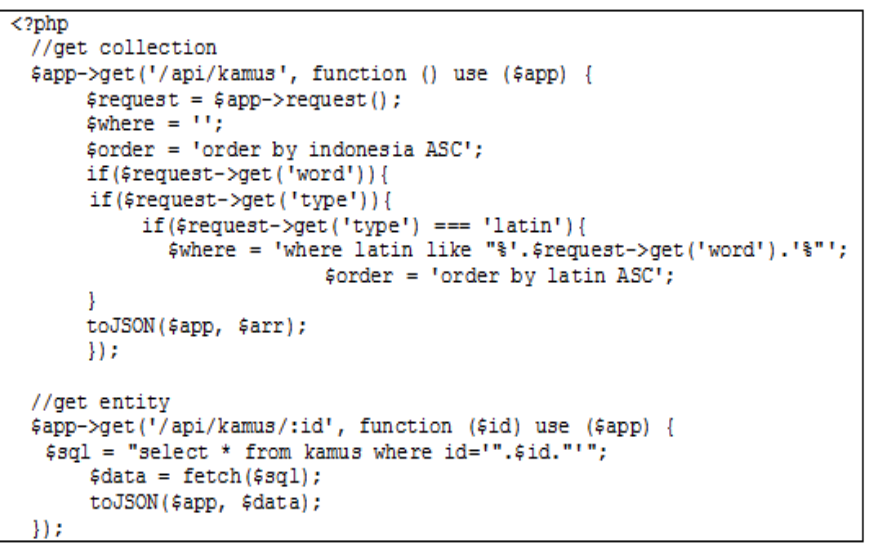

Gbr. 11 Potongan skrip modul API

Setelah administrator dan pengguna melakukan pengujian secara langsung, dapat dilihat bahwa sistem bawaan bekerja sesuai dengan urutan sistem yang sebelumnya dirancang, setelah itu sistem juga dijalankan sesuai dengan permintaan pengguna (aplikasi Android). Dalam proses menciptakan sistem, komunikasi dengan pengguna telah diharapkan dengan perangkat lunak yang dibuat untuk membantu dalam proses pelaporan bencana yang sering terjadi di kehidupan sehari-hari seperti kebakaran rumah, gempa bumi, angin puting beliung dan lain-lain sehingga masyarakat semakin mudah untuk berinteraksi dengan pihak BNPB.

Dalam aplikasi terdapat modul API (Application Programming Interface) dibuat yang dibuat menggunakan program PHP. Modul API ini berisi modul yang digunakan untuk query data secara langsung antara aplikasi smartphone dan database. Sedangkan Peran framework Cordovaadalah seperti kerangka kerja yang berisi HTML5, CSS dan Javascript. HTML5, CSS dan Javascript digunakan sebagai template untuk pengembangan aplikasi atau kamus interpretasi yang dikemas dalam kerangka antarmuka pengguna Onsen. Struktur API dapat dilihat pada Gbr.11.

Pada skrip coding terdiri dari 2 bagian: collection dan get_collection. Dalam get_collection, apabila terjadi request dari aplikasi smartphone akan dilanjutkan dalam basis data dalam bentuk query. Selain itu, hasil query dianalisis dalam bentuk kode JSON. Di bagian kedua dari get-entity, data kemudian diinterpretasikan sesuai dengan permintaan dan dikembalikan dalam bentuk kode JSON. Untuk menjalankan fungsi JSON, Javascript diperlukan dalam file "lapor.js".

\section{KESIMPULAN DAN SARAN}

Berdasarkan hasil penelitian tentang perangkat lunak aplikasi mobile hybrid yang menggunakan teknologi cordova di Badan Penanggulangan Bencana wilayah Sumatera Selatan, peneliti menyimpulkan bahwa dengan menggunakan metode mobile hybrid pengembangan perangkat lunak ponsel lebih efektif. Dengan perangkat lunak mobile hybrid, perangkat lunak ini dapat mempermudah agen penanggulangan bencana di Sumatra Selatan untuk menerima laporan tentang bencana yang terjadi di masyarakat dan dapat dengan cepat menjadi bencana. Penggunaan teknologi cordova sangat berguna dalam pengembangan perangkat lunak seluler karena dengan teknologi pengembang cordova Anda memiliki akses ke fungsi perangkat asli seperti kamera, akselerometer dengan JavaScript.

Penelitian ini dilakukan pada sebatas prototype sistem, sehingga untuk proses penelitian selanjutnya dapat diimplementasikan dan dilakukan analisis serta evaluasi sistem yang lebih detail.

\section{UCAPAN TERIMA KASIH}

Ucapan terima kasih kepada seluruh rekan-rekan kerja yang telah ikut berpartisipasi memberikan masukkan dan kritiknya mengenai aplikasi pelaporan bencana alam di badan penanggulangan bencana nasional wilyaha Sumatera Selatan. Tidak lupa juga peneliti ucapkan terima kasih kepada Universitas Bina Darma dalam memberikan fasilitas untuk penelitian ini.

\section{DAFTAR PUSTAKA}

[1] D. Timbowo, "Manfaat Penggunaan Smartphone Sebagai Media Komunikasi," e-journal "Acta Diurna," vol. V, no. 2, 2016.

[2] A. Asmura, A. Afriyudi, and A. Ari Muzakir, "IMPLEMENTASI OBJECT ORIENTED HYPERMEDIA DESIGN METHOD PADA SISTEM INFORMASI AKADEMIK SMK MADYATAMA,” 2017.

[3] H. Heitkötter, S. Hanschke, and T. A. Majchrzak, "Evaluating crossplatform development approaches for mobile applications," in Lecture Notes in Business Information Processing, 2013, vol. 140 LNBIP, pp. 120-138.

[4] A. Holzinger, P. Treitler, and W. Slany, "Making apps useable on multiple different mobile platforms: On interoperability for business application development on smartphones," in Lecture Notes in Computer Science (including subseries Lecture Notes in Artificial Intelligence and Lecture Notes in Bioinformatics), 2012, vol. 7465 LNCS, pp. 176-189.

[5] R. Francese, M. Risi, G. Tortora, and G. Scanniello, "Supporting the development of multi-platform mobile applications," in Proceedings of IEEE International Symposium on Web Systems Evolution, WSE, 2013, pp. 87-90.

[6] R. Gangundi, "Smartphone Application Development using Cross Platform Frameworks," in Proceedings of the National Conference on Information and Communication Technology, NMIMS University, Mumbai, India, 2010.

[7] A. Muzakir, "Prototyping Aplikasi E-Health sebagai Bagian Pengenalan Obat-Obatan Dengan Teknologi Cross- Platform," $J$. Inform. J. Pengemb. IT, vol. 3, no. 1, pp. 61-66, 2018.

[8] I. G. Suardika, "RANCANG BANGUN SISTEM INFORMASI ERESEARCH STIKOM BALI MULTI PLATFORM SMARTPHONE BERBASIS PHONEGAP," in Seminar Nasional Informatika (SNIf), 2017, vol. 1, no. 1, pp. 45-49.

[9] A. Muzakir, "Framework Phonegap Sebagai Teknologi Cross-Platform Mobile Development: Studi Kasus Kamus Tumbuhan,” KNTIA, vol. 4, 2017.

[10] W. Mobile and A. Development, Smartphone Cross-Platform Development, vol. 2010. 2010. 
[11] R. S. Pressman, Software engineering (7rd ed.): a practitioner's approach, vol. 7, no. 1. 2010.

[12] S. Cha and Y. Yun, "Smartphone Application Development using HTML5- based Cross-Platform Framework," in The 5th International
Conference on Advanced Science and Technology, 2013, vol. 20, pp. 8-10.

[13] M. Panhale, "Building Blocks of HMAD," in Beginning Hybrid Mobile Application Development, 2016, pp. 21-53. 